\title{
Validation of a clinical simulation setting in the management of postpartum haemorrhage
}

\author{
Validação de cenário de simulação clínica no manejo da hemorragia pós-parto \\ Validación de escenario de simulación clínica en el manejo de la hemorragia posparto
}

\section{Priscyla de Oliveira Nascimento Andrade \\ ORCID: 0000-0002-1177-0137 \\ Sheyla Costa de Oliveira' \\ ORCID: 0000-0003-0485-1729}

Sheila Coelho Ramalho Vasconcelos Morais' ORCID: 0000-0001-9831-0338

Tatiane Gomes Guedes' ORCID: 0000-0001-7149-2290

Geyslane Pereira de Melo' ORCID: 0000-0001-7246-8831

Francisca Marcia Pereira Linhares' ORCID:0000-0001-9778- 5024

'Universidade Federal de Pernambuco, Departamento de Enfermagem. Recife, Pernambuco, Brasil.

How to cite this article: Andrade PON, Oliveira SC, Morais SCRV, Guedes TG, Melo GP, Linhares FMP. Validation of a clinical simulation setting in the management of post partum haemorrhage. Rev Bras Enferm. 2019;72(3):624-31. doi: http://dx.doi.org/10.1590/0034-7167-2018-0065

Corresponding Author:

Priscyla de Oliveira Nascimento Andrade E-mail: pricila_nas@yahoo.com.br

Submission: 04-13-2018 Approval: 02-08-2019

\section{ABSTRACT}

Objective: To construct and validate a clinical simulation setting for postpartum haemorrhage. Method: Quantitative research of methodological development, carried out from May to July of 2016 with 22 expert judges and 30 students. Analysis was performed from descriptive statistics, Binomial Test and Content Validity Index (CVI), considering $\mathrm{CVI} \geq 80 \%$. Results: Setting construction was based on learning objectives, fidelity, evaluation tool, pre-setting activities and debriefing. Agreement, regarding its validity, was satisfactory in the 23 items analyzed. Items evaluated by judges had $\mathrm{CVI}>0.90$; in the evaluation by students, CVI was $>0.95$. Conclusion: It was considered validated and suitable for training and use by nursing students. Other studies should be carried out in order to test its effectiveness in the construction of theoretical and practical knowledge of both nursing students and nurses during Permanent Education. Descriptors: Validation Studies; Nursing; Obstetrics; Nursing Education; Simulation Training.

\section{RESUMO}

Objetivo: Construir e validar um cenário de simulação clínica para a hemorragia pósparto. Método: Pesquisa quantitativa, de desenvolvimento metodológico, realizada de maio a julho de 2016 com 22 juízes especialistas e 30 discentes. A análise foi realizada a partir da estatística descritiva, Teste Binomial e Índice de Validade de Conteúdo (CVI), considerando o CVI $\geq 80 \%$. Resultados: A construção do cenário foi baseada nos objetivos de aprendizagem, fidelidade, instrumento de avaliação, atividades desenvolvidas antes do cenário e debriefing. A concordância, quanto à sua validade, foi satisfatória nos 23 itens analisados. Os itens avaliados pelos juízes tiveram CVI >0,90; na avaliação pelos discentes, o CVI > 0,95. Conclusão: Considerou-se validado e adequado para capacitação e utilização pelos discentes de enfermagem. Outros estudos deverão ser realizados, a fim de testar sua eficácia na construção do conhecimento teórico e prático tanto de discentes de enfermagem quanto por enfermeiros durante a Educação Permanente.

Descritores: Estudos de Validação; Enfermagem; Obstetrícia; Educação em Enfermagem; Treinamento por Simulação.

\section{RESUMEN}

Objetivo: Construir y validar un escenario de simulación clínica para la hemorragia posparto. Método: Investigación cuantitativa de desarrollo metodológico realizada de mayo a julio 2016, con 22 jueces especialistas y 30 estudiantes. El análisis fue realizado a partir de la estadística descriptiva, prueba binomial e Índice de Validez de Contenido $(\mathrm{CVI})$, considerándose el $\mathrm{CVI} \geq 80 \%$. Resultados: La construcción del escenario fue baseada en los objetivos de aprendizaje, fidelidad, instrumento de evaluación, actividades desarrolladas antes del escenario y debriefing. La concordancia en cuanto su validez fue satisfactoria en los 23 ítems analizados; esos ítems evaluados por los jueces tuvieron $\mathrm{CVI}>0,90$, y en la evaluados por los discentes el CVI >0,95. Conclusión: Se consideró validado y adecuado para capacitación y utilización por los alumnos de Enfermería. Otros estudios deberán ser realizados a fin de probar su eficacia en la construcción del conocimiento teórico y práctico, tanto de discentes de Enfermería como por enfermeros durante educación continuada.

Descriptores: Estudios de Validación; Enfermería; Obstetricia; Educación en Enfermería; Entrenamiento por Simulación. 


\section{INTRODUCTION}

Postpartum haemorrhage (PPH) affects approximately $2 \%$ of all women in the puerperal period. PPH is associated with approximately one-quarter of all maternal deaths worldwide and has contributed to severe maternal morbidity and prolonged disability through association with more substantial blood loss, including progression to shock and organic dysfunction ${ }^{(1)}$.

Midwife nurses, most of times, are who first identify and initiate PPH treatment. Thus, increase in quality and number of the nursing professional's qualifications translates into benefits for the patient ${ }^{(2)}$. The clinical simulation technique has been used as an important teaching tool and active methodology to be used in training of nurses and in Permanent Education of health professionals. This technique has been increasingly used because it is an important training resource for these professionals, so that they can develop skills, and communication, health care, decision-making and leadership abilities, being essential to resolution of the exposed clinical situation ${ }^{(3)}$.

Thus, the use of clinical simulation presents itself as a viable teaching strategy to prepare students and professionals in the setting of care practice. It can be used even in the academic and hospital environment. Simulation allows health professionals to identify behaviors that need improvement by offering the opportunity to practice and develop skills in a non-threatening environment away from patient care since stress and anxiety can increase the chances of error not acceptable in actual practice. Techniques referring to resuscitation and stabilization should be dominated for hospital practice aiming to improve the performance of students and professionals ${ }^{(4)}$. Clinical simulation in Obstetrical Nursing improved care provision to the vulnerable population and contributed to reduce the morbidity and mortality rates associated with preeclampsia and eclampsia or other emergencies ${ }^{(5)}$.

In PPH care, training using clinical simulation improved realtime blood loss estimates and allowed learners to detect and treat early because they avoid underestimation of blood loss and treatment is postponed ${ }^{(3)}$. This teaching methodology has also shown potential in emergency management with pre-eclampsia and eclampsia. It positively affects efficacy of nurses in the treatment of this obstetric urgency; in addition to suggesting that the management of other high risk and low incidence obstetric emergencies can also be improved ${ }^{(5)}$.

In this sense, the clinical simulation script construction in the management of PPH is able to strengthen the theory/practice relationship and contribute to the training of more critical and reflexive nurses, developing skills and abilities in the care of women with PPH. To do so, it is necessary to validate a simulation setting by expert judges and target public; since it must be ensured that it has integrity, reproducibility and is in line with the recommended standards for the clinical simulation setting's construction.

\section{OBJECTIVE}

This study aims to build and validate clinical simulation setting for PPH.

\section{METHODS}

\section{Ethical aspects}

Ethical precepts established by Resolution 466/2012 and $506 / 16$ of the National Health Council were followed, so that the proposal of the study was appreciated and approved by the Research Ethics Committee Involving Human Beings of the Universidade Federal de Pernambuco.

\section{Design, place of study and period}

This is a methodological research for the construction and validation of a setting of clinical simulation in the management of PPH, carried out from May to July, 2016. Simulation setting was constructed after surveying contents from the literature, and was based on the judgment of expert judges and target audience that analyzed representativeness of the content and its adequacy ${ }^{(6)}$.

\section{Population or sample, criteria of inclusion and exclusion}

The criteria established for the selection of judges were adapted from those proposed by Fehring. Judges whose professional profile was compatible with a minimum score of 7 points ${ }^{(7)}$. Criteria: have a doctorate in nursing or related areas $=4$; Master's Degree in nursing or related areas $=4$; dissertation in the area of Women's Health/Obstetrics/simulation $=1$; articles published in one of the cited areas $=2$; practice or teaching in one of the areas $=2 ;$ and specialization in the area of Women's Health/Obstetrics $=2$. All judges had at least specialization.

Sample was determined by the use of calculation formula based on proportion ${ }^{(8)}$. Sample size was calculated from formula: $\mathrm{N}=$ $Z a^{2} . P(1-P) / e^{2}$. Where: $N=$ sample size; $P=$ proportion of judges $(85 \%) ; \mathrm{e}=$ proportional difference acceptable in relation to what would be expected (15\%); $Z a=1.96$ (95\% desired confidence); obtaining a final sample of 22 specialists/students. 22 judges and 30 students participated in the nursing course/UFPE.

Selection of judges was for convenience, carried out by the Lattes Platform of the curriculum of researchers, available in the Conselho Nacional de Desenvolvimento Científico e Tecnológico (CNPq - National Council for Scientific and Technological Development) portal. Inclusion criteria of students were: to have studied nursing in women's health, be 18 years old or older. Exclusion criteria were: students with training in related areas that allows a prior preparation in the management of $\mathrm{PPH}$. The criterion of choice was the use of intentional non-probabilistic sampling ${ }^{(6)}$.

An electronic form was created with the help of Google Forms"; and was sent by e-mail to judges after initial contact, composed of invitation letter, Free Informed Consent Form and a form containing: characterization form, setting script, and content and appearance validation form. For students, forms were in printed form, which were delivered and collected personally by the researcher. Validation form was built by authors. Evaluation carried out by judges contained three categories: objective, structure, presentation and relevance. The one performed by the target audience has five domain categories: objectives, organization, writing style, appearance and motivation. Each category was analyzed using the Likert 
scale ${ }^{(9)}$, with five levels of responses: I totally agree, I partially agree, I neither agree nor disagree, I partially disagree, I totally disagree.

\section{Study protocol}

A survey of the contents was carried out by searching the literature for specific books on the subject, scientific articles and recommendations from World Health Organization (WHO) for PPH prevention and treatment (2014) $)^{(1)}$; textual elaboration of the setting script following a pre-established model(10-11).

Following the pre-built model ${ }^{(10-11)}$, the first step was to determine the learning objective. To this end, it was established that the nurse/student could adequately and in a team conduct the care of a puerperal patient with PPH. The activity included: identifying puerperae with blood loss greater than $500 \mathrm{ml}$ with clinical signs of hypovolemic shock and/or greater than $1000 \mathrm{ml}$, with or without clinical signs of hypovolemic shock; enabling $\mathrm{PPH}$ protocol; identifying and correcting the pathway laceration and hypotonic uterus, causes of hemorrhage; and recording the nursing process in medical records.

The second step was to include in the simulation a clinical case, with physiological responses to each intervention of students. $A$ low fidelity manikin was used, with the use of the female pelvis that allowed visualization of the vulva and vaginal introitus. Simulation was performed in a place of the delivery room setting. Three participants were selected and named team members: one nursing technician and two nurses; it was established that simulation had an estimated duration of 20 minutes, being classified as of medium complexity, according to the clinical case's complexity.

The third step, in the setting construction, an assessment/resolution tool of problems was constructed: after presentation of the clinical picture, students were asked to provide patient care. Scenes were developed and skills and abilities expected during the simulation were set. Thus, a checklist was created to evaluate actions performed according to: communication, physical examination, signs and symptoms, monitoring and nursing process recording, Chart 1.

Chart 1 - Checklist of actions in PPH simulation, Recife, PE, Brazil, 2016

\begin{tabular}{|c|c|c|c|c|}
\hline \multicolumn{3}{|c|}{$\begin{array}{c}\text { Expected nursing activities } \\
\text { Performed } \\
\text { No }\end{array}$} & \multicolumn{2}{|l|}{ Performance } \\
\hline \multirow{5}{*}{ Communication } & \multicolumn{2}{|c|}{ To introduce yourself to the woman and call for help } & ( ) Correct ( ) Incorrect & () \\
\hline & \multicolumn{2}{|c|}{ To check and request time record } & () Correct ( ) Incorrect & ( ) \\
\hline & \multicolumn{2}{|c|}{ To ask the patient what she is feeling } & ( ) Correct ( ) Incorrect & () \\
\hline & \multicolumn{2}{|c|}{ To explain patient behaviors } & ( ) Correct ( ) Incorrect & () \\
\hline & \multicolumn{2}{|c|}{ Comorbidities; Medication Use; Allergies } & ( ) Correct ( ) Incorrect & $($ ( ) \\
\hline \multirow{5}{*}{ To Perform Physical Examination } & \multicolumn{2}{|c|}{ To carry out the therapeutic approach } & ( ) Correct ( ) Incorrect & $($ ( ) \\
\hline & \multicolumn{2}{|c|}{ To perform skin and mucous membrane inspection } & ( ) Correct ( ) Incorrect & () \\
\hline & \multicolumn{2}{|c|}{ To perform palpation of the uterine height and tonus } & ( ) Correct ( ) Incorrect & () \\
\hline & \multicolumn{2}{|c|}{ To gauge vital signs } & ( ) Correct ( ) Incorrect & ( ) \\
\hline & \multicolumn{2}{|c|}{ To check tonus, tissue, path and thrombin } & ( ) Correct ( ) Incorrect & ( ) \\
\hline & \multicolumn{2}{|c|}{ To check A-B-C } & ( ) Correct ( ) Incorrect & ( ) \\
\hline & \multicolumn{2}{|c|}{ To attempt to report dry mouth and thirst } & ( ) Correct ( ) Incorrect & () \\
\hline & \multicolumn{2}{|c|}{ To attempt to report respiratory distress } & ( ) Correct ( ) Incorrect & () \\
\hline & \multicolumn{2}{|c|}{ To identify drowsiness } & ( ) Correct ( ) Incorrect & () \\
\hline & \multicolumn{2}{|c|}{ To identify cold, damp, and hypocritical skin } & ( ) Correct ( ) Incorrect & () \\
\hline & \multicolumn{2}{|c|}{ To check decreased peripheral tissue perfusion } & ( ) Correct ( ) Incorrect & $($ ) \\
\hline & \multicolumn{2}{|c|}{ To verify uterine involution } & ( ) Correct ( ) Incorrect & () \\
\hline & \multicolumn{2}{|c|}{ To pay attention to $\mathrm{HR}^{*}: 110 \mathrm{bpm}$ and $\mathrm{BP}+: 80 \times 50 \mathrm{~mm} / \mathrm{Hg}$} & ( ) Correct ( ) Incorrect & () \\
\hline & \multicolumn{2}{|c|}{ To pay attention to weak and fast pulse } & ( ) Correct ( ) Incorrect & ( ) \\
\hline To Identify Signs and Symptoms of Risk for & \multicolumn{2}{|c|}{ To pay attention to RR $\neq: 24 \mathrm{mov} / \mathrm{min}$ and $\mathrm{SO}^{2}: 90 \%$} & ( ) Correct ( ) Incorrect & ( ) \\
\hline & \multicolumn{2}{|c|}{ To pay attention to $\mathrm{T} \S: 35.5^{\circ} \mathrm{C}$} & ( ) Correct ( ) Incorrect & () \\
\hline & \multicolumn{2}{|c|}{ To request venipuncture and collect blood for lab tests } & ( ) Correct ( ) Incorrect & ( ) \\
\hline & \multicolumn{2}{|c|}{ To position patient with slightly elevated headboard } & ( ) Correct ( ) Incorrect & () \\
\hline & \multicolumn{2}{|c|}{ To install $0.9 \%$ SS II in rapid infusion } & ( ) Correct ( ) Incorrect & ( ) \\
\hline & \multicolumn{2}{|c|}{ To administer oxygen by nasal catheter at $3 \mathrm{~L} / \mathrm{min}$} & ( ) Correct ( ) Incorrect & () \\
\hline & \multirow{4}{*}{ 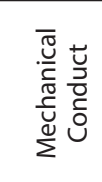 } & To perform Uterine Massage & ( ) Correct ( ) Incorrect & () \\
\hline & & \begin{tabular}{|l} 
To perform manual bi compression \\
\end{tabular} & ( ) Correct ( ) Incorrect & $($ ) \\
\hline & & To empty the bladder & ( ) Correct ( ) Incorrect & ( ) \\
\hline & & To review birth canal & ( ) Correct ( ) Incorrect & ( ) \\
\hline
\end{tabular}




\begin{tabular}{|c|c|c|c|c|}
\hline \multicolumn{3}{|c|}{$\begin{array}{c}\text { Expected nursing activities } \\
\text { Performed } \\
\text { No }\end{array}$} & \multicolumn{2}{|l|}{ Performance } \\
\hline \multirow{5}{*}{$\begin{array}{c}\text { To Identify Signs and Symptoms of Risk for } \\
\text { Hypovolemic Shock }\end{array}$} & \multirow{3}{*}{$\stackrel{\text { ֻั }}{\frac{n}{2}}$} & Intramuscular oxytocin 10 ףIU & ( ) Correct ( ) Incorrect & () \\
\hline & & Intravenous oxytocin 20 ףIU in SS & ( ) Correct ( ) Incorrect & ( ) \\
\hline & & To keep intravenous oxytocin & ( ) Correct ( ) Incorrect & () \\
\hline & & To view lacerations & ( ) Correct ( ) Incorrect & () \\
\hline & & To carry out raffia of bleeding lacerations & ( ) Correct ( ) Incorrect & ( ) \\
\hline \multirow{2}{*}{ Monitoring } & \multicolumn{2}{|c|}{ To identify VVSS changes ** } & ( ) Correct ( ) Incorrect & () \\
\hline & \multicolumn{2}{|c|}{ To perform clinical monitoring } & ( ) Correct ( ) Incorrect & ( ) \\
\hline \multirow{3}{*}{ Nursing Process } & \multicolumn{2}{|c|}{ Nursing Diagnosis } & ( ) Correct ( ) Incorrect & () \\
\hline & \multicolumn{2}{|c|}{ Expected results } & ( ) Correct ( ) Incorrect & () \\
\hline & \multicolumn{2}{|c|}{ Prescription and nursing evolution } & ( ) Correct ( ) Incorrect & () \\
\hline
\end{tabular}

Note: *HR- Heart Rate, $+B P$ - Blood Pressure, $\neq R R$ - Respiratoy Rate, $\S T$ - Temperature, SS II - Saline Solution, $\uparrow I U$ - Internacional Units, ${ }^{* *}$ VVSS - Vital Signs.

Chart 2 - Description of statements used in the PPH simulation. Recife, PE, Brazil, 2016

\begin{tabular}{|c|c|}
\hline Character & Script \\
\hline Nursing Tech. & $\begin{array}{l}\text { - The patient has just given birth, is lying down, a little } \\
\text { tired. } \\
\text { The nurse is called because of the bleeding } \\
\text { Expresses tranquility } \\
\text { - There is active bleeding, drowsiness, cold, moist and } \\
\text { hypocorous skin, decreased peripheral tissue perfusion, } \\
\text { uterine involution at the umbilical and hypotonic scar level. }\end{array}$ \\
\hline Nurse & $\begin{array}{l}\text { It is presented and questioned what the patient is } \\
\text { feeling }\end{array}$ \\
\hline Patient & $\begin{array}{l}\text { - I'm tired, with dark vision. Oh what a dry mouth! I'm } \\
\text { thirsty! I'm feeling short of breath! (Patient) }\end{array}$ \\
\hline Nursing Tech. & $\begin{array}{l}\text { Provide the following information when you notice } \\
\text { or are asked to evaluate these standards by students: } \\
\text { - Conscious and oriented - } H R^{*}: 110 \mathrm{bpm} \text { - RRt: } 24 \mathrm{irpm} \\
\text { - Weak and fast pulse - BP }: 80 \times 50 \mathrm{mmHg}-\mathrm{T \S}: 35.5^{\circ} \mathrm{C} \\
\text { - Saturation: } 90 \%\end{array}$ \\
\hline Nurse & Starts PPH protocol \\
\hline Nursing Tech. & $\begin{array}{l}\text { Wait for student's initial behavior. After some } \\
\text { procedures give new data. Conscious and oriented - } \\
\text { HR: } 112 \mathrm{bpm} \text { - BP } 100 \times 60 \mathrm{mmHg} \\
\text { After oxytocin administration: How good that uterus } \\
\text { contracted after oxytocin, but bleeding remains. } \\
\text { (Nursing Technician) } \\
\text { Expects a little student's reasoning. If you do not } \\
\text { leave for birth canal review: } \\
\text { - It is still bleeding! (Nursing Technician) }\end{array}$ \\
\hline Nurse & Attempts to identify other causes of PPH II \\
\hline Nursing Tech. & $\begin{array}{l}\text { After oxytocin and lacerations raffia: } \\
\text { - Yeah, looks like the bleeding stopped. Still good! } \\
\text { (Nursing Technician) } \\
\text { - HR: } 86 \mathrm{bpm} \text { - Full and regular pulse; - RR: } 18 \mathrm{irpm} \text {; BP: } \\
90 \times 60 \mathrm{~mm} / \mathrm{Hg} ;-\mathrm{T}: 36{ }^{\circ} \mathrm{C} \text { - Saturation: } 98 \%\end{array}$ \\
\hline Patient & Mentions improvement \\
\hline
\end{tabular}

Note: *HR- Heart Rate, $+R R$ - Respiratory Rate, $\neq B P-B$ Blood Pressure, $\S T$ - Temperature, PPH II - postpartum haemorrhage.
The fourth step was to establish prerequisites for participation in the simulation and support needed by students. As it is a specific nursing care it was established that for participation in the simulation, students should attend a class on the subject beforehand and be aware of the physiology and anatomy of labor, delivery and immediate puerperium; read the treatment protocol for $\mathrm{PPH}$; knowledge of biosafety resources and materials used. Two "actors" made part of the setting in order to help clarify the clinical situation. One made the patient's voice and the other performed a nurse technician who informed, when requested, the patient's clinical signs. A script with actor dialogues and participant (nurse) of the simulation was elaborated to ensure information quality during the setting development, as shown in Chart 2.

The fifth step in the setting was the debriefing construction, conducted after the simulation with all participants. Issues related to self-assessment about care, feelings about the situation lived, skills developed, a reflection of the positives and opportunities for improvement.

\section{Analysis of results, and statistics}

Data collected in the validation stage were analyzed by the $\mathrm{IBM}^{\circ} \mathrm{SPSS}^{\circ}$ Statistics, version 20.0, describing the absolute, mean and Standard Deviation. For content validation, the Binomial Test ${ }^{(9)}$ was applied to each item of the form, verifying the proportion of agreement between judges, with an agreement ratio equal to or greater than $85 \%(P \geq 85 \%)$ and a significance level (a) of $5 \%$. Thus, $p$-values greater than 0.05 indicate the proportion of judges who agreed with the adequacy and relevance of the simulation setting ${ }^{(8)}$.

For analysis in relation to the degree of agreement of items, Content Validity Index was calculated by means of three mathematical equations: I-CVI (Item-level Contente Validity Index), S-CVI/ AVE (Scale-level Contente Validity Index, Averange Calculation Method) e S-CVI (Scale-level Contente Validity Index). The item that obtained a mean of 0.80 or greater was considered as desired in the validation ${ }^{(6)}$. For students' analysis understanding of the simulation route, the calculation of the I-CVI was also performed for each item of the appearance validation form. 


\section{RESULTS}

Regarding the content validation process, of the 22 judges, the majority had assisting experience in Women's Health/Obstetrics $(n=19)$, and teaching experience $(n=21)$ in higher education institutions. Three had experience with clinical simulation and specialization in emergency and adult emergency. All judges were female $(n=22)$. Mean age was 45.4 years ( $S D+9.3$ years). The mean time of training was 35.3 years (SD 7.7 years), with teaching time of 7.8 years (SD+8.1 years). Of those who worked in care, all had specialization in Women's Health/Obstetrics and Master's Degree.
Agreement between judges for the evaluated items was satisfactory. $P$ value was $>0.05$ in the 23 items, indicating the proportion of judges agreeing with the adequacy and pertinence of the clinical simulation setting. All items in the objective, structure, presentation and relevance categories were satisfactorily evaluated. There was no need to adjust the content of the roadmap to achieve the proposed objectives.

Items agreement expressed by the I-CVI calculation, separately, can be visualized in Table 1. It is verified that the I-CVI value was greater than 0.90 in all evaluated items. I-CVI mean for clinical simulation setting was 0.97. Agreement ratio (S-CVI/AVE) was above 0.91 for all judges. S-CVI value was 0.976 (Table 1).

Table 1 - Agreement of items for content validation and appearance of the clinical simulation setting, according to judges. Recife, PE, Brazil, 2016

\begin{tabular}{|c|c|c|c|c|c|c|}
\hline \multirow{2}{*}{ Items Evaluated } & \multicolumn{3}{|c|}{ Agreement } & \multirow{2}{*}{$\mathbf{p}^{*}$} & \multirow{2}{*}{$\mathrm{Pt}$} & \multirow{2}{*}{$\mathbf{I}-\mathbf{C V I}$} \\
\hline & Yes & Null & No & & & \\
\hline \multicolumn{7}{|l|}{ Objetcive } \\
\hline Contents are consistent with the objective of the clinical simulation setting & 22 & 0 & 0 & 1.000 & 1.000 & 1.00 \\
\hline Learning objectives are clear and concise & 22 & 0 & 0 & 1.000 & 1.000 & 1.00 \\
\hline Content of the setting facilitates critical thinking & 22 & 0 & 0 & 1.000 & 1.000 & 1.00 \\
\hline Information presented is scientifically correct & 21 & 0 & 1 & 0.972 & 0.954 & 0.95 \\
\hline There is a logical sequence of proposed content & 21 & 0 & 1 & 0.972 & 0.954 & 0.95 \\
\hline Information presented in the setting covers well the content about PPH§ & 21 & 0 & 1 & 0.972 & 0.954 & 0.95 \\
\hline Information/content is important for the quality of care provided & 22 & 0 & 0 & 1.000 & 1.000 & 1.00 \\
\hline Objective of the setting invites/instigates changes of behavior and attitude of students & 21 & 0 & 1 & 0.972 & 0.954 & 0.95 \\
\hline \multicolumn{7}{|l|}{ Structure and Presentation } \\
\hline Setting script is appropriate for nursing students & 22 & 0 & 0 & 1.000 & 1.000 & 1.00 \\
\hline Language used is easy to understand by students & 22 & 0 & 0 & 1.000 & 1.000 & 1.00 \\
\hline Setting has attractive visuals that keep the attention of students & 20 & 1 & 1 & 0.863 & 0.909 & 0.91 \\
\hline Data are presented in a structured and objective way & 22 & 0 & 0 & 1.000 & 1.000 & 1.00 \\
\hline Presentation of setting contributes to students'learning & 22 & 0 & 0 & 1.000 & 1.000 & 1.00 \\
\hline Contains at least four evidence to confirm a highly accurate diagnosis & 21 & 0 & 1 & 0.972 & 0.954 & 0.95 \\
\hline Contextual details provide clues based on desired results & 21 & 0 & 1 & 0.972 & 0.954 & 0.95 \\
\hline Patient profile provides sufficient data to perform a clinical trial & 22 & 0 & 0 & 1.000 & 1.000 & 1.00 \\
\hline Pages or sections appear organized & 20 & 0 & 2 & 0.863 & 0.909 & 0.91 \\
\hline \multicolumn{7}{|l|}{ Relevance } \\
\hline Setting allows the transfer of knowledge in relation to the management of PPH & 22 & 0 & 0 & 1.000 & 1.000 & 1.00 \\
\hline The theme portrays key aspects that need to be strengthened & 22 & 0 & 0 & 1.000 & 1.000 & 1.00 \\
\hline The model allows the transfer and generalization of learning to different contexts & 20 & 1 & 1 & 0.863 & 0.909 & 0.91 \\
\hline Setting script proposes the construction of knowledge & 22 & 0 & 0 & 1.000 & 1.000 & 1.00 \\
\hline Can be used by health professionals/or educators & 22 & 0 & 0 & 1.000 & 1.000 & 1.00 \\
\hline Clinical simulation setting in the management of PPH may circulate in the scientific & 22 & 0 & 0 & 1.000 & 1.000 & 1.00 \\
\hline S-CVIII & & & & & & 0,976 \\
\hline
\end{tabular}

Note: *-CVI-Item-Level Content Validity Índex, TPPH- postpartum haemorrhage, $\neq$ S-CVI - Scale-Level Content Validity Index.

Table 2 - Agreement of the items to validate the appearance of the clinical simulation setting according to the target audience. Recife, PE, Brazil, 2016.

\begin{tabular}{|c|c|c|c|c|}
\hline \multirow{2}{*}{ Items Evaluated } & \multicolumn{3}{|c|}{ Agreement } & \multirow{2}{*}{$\mathbf{I}-\mathbf{C V I} *$} \\
\hline & Yes & Null & No & \\
\hline \multicolumn{5}{|l|}{ Objective } \\
\hline Setting meets the proposed objective & 30 & 0 & 0 & 1.00 \\
\hline Help with the quality of PPH learning $†$ & 30 & 0 & 0 & 1.00 \\
\hline Setting is suitable for you to use at the moment & 30 & 0 & 0 & 1.00 \\
\hline \multicolumn{5}{|l|}{ Organization } \\
\hline Title is attractive and indicates the content of the setting & 30 & 0 & 0 & 1.00 \\
\hline Size of the title and the content in the topics are suitable & 29 & 0 & 1 & 0.97 \\
\hline Topics have logical sequence & 30 & 0 & 0 & 1.00 \\
\hline There is consistency between the objectives and content of the & 30 & 0 & 0 & 1.00 \\
\hline
\end{tabular}




\begin{tabular}{|c|c|c|c|c|}
\hline \multirow{2}{*}{ Items Evaluated } & \multicolumn{3}{|c|}{ Agreement } & \multirow{2}{*}{$\mathrm{I}-\mathrm{CV} \mathbf{I}^{*}$} \\
\hline & Yes & Null & No & \\
\hline \multicolumn{5}{|l|}{ Writing Style } \\
\hline Writing is clear and objective & 30 & 0 & 0 & 1.00 \\
\hline Text is interesting & 30 & 0 & 0 & 1.00 \\
\hline Vocabulary is accessible & 30 & 0 & 0 & 1.00 \\
\hline There is an association of the theme of each section with the corresponding text & 30 & 0 & 0 & 1.00 \\
\hline Writing style corresponds to the level of your knowledge & 30 & 0 & 0 & 1.00 \\
\hline \multicolumn{5}{|l|}{ Appearance } \\
\hline Pages and section appear organized & 30 & 0 & 0 & 1.00 \\
\hline Setting appearance is simple and clear & 30 & 0 & 0 & 1.00 \\
\hline Setting content is attractive & 30 & 0 & 0 & 1.00 \\
\hline content is expressive and sufficient & 30 & 0 & 0 & 1.00 \\
\hline \multicolumn{5}{|l|}{ Motivation } \\
\hline Setting is appropriate for undergraduate students profile & 29 & 0 & 1 & 0.97 \\
\hline Content is logical and attractive & 30 & 0 & 0 & 1.00 \\
\hline Interaction is invited by texts and suggests actions & 29 & 0 & 1 & 0.97 \\
\hline Instigates changes in behavior and attitude during care & 30 & 0 & 0 & 1.00 \\
\hline Setting proposes new knowledge for students & 30 & 0 & 0 & 1.00 \\
\hline $\mathrm{S}-\mathrm{CVI}$ & & & & 0.976 \\
\hline
\end{tabular}

Note: $N *$ I-CVI-Item-Level Content Validity Índex, $+\mathrm{PPH}$ - postpartum haemorrhage, $\neq S$-CVI - Scale-Level Content Validity Index.

\section{DISCUSSION}

Deaths from PPH are caused by delays in identification and diagnosis. Teams need to be able to intervene early in order to reduce maternal morbidity and mortality ${ }^{(1)}$. Thus, clinical simulation on PPH construction will take knowledge in a dynamic and interactive way, in order to provoke reflections that lead to the change of student/professional behavior when exposed to this situation in the practice of care.

Impact of training through clinical simulations is significant in reducing maternal mortality because it ensures that all professionals caring for women during childbirth have the opportunity to learn the skills and abilities needed to manage PPH ${ }^{(12)}$. The use of clinical simulation in the context of education demands well-planned and structured criteria, with suitable methodology, trained professionals and efficient resources so that the established objectives are achieved. Taking into consideration the study setting construction, similar steps were used in the setting construction for the PPH management in UK, whose development phases were: selection of simulator and environment, determination of duration of simulation, construction of a study and an evaluation tool, which was applied before and after simulation. However, such a setting that was built systematically did not have its content validated ${ }^{(13)}$.

For the simulation success, it is important that the setting is based on the learning objectives ${ }^{(14)}$. When the objectives of the teaching strategy and the setting are well delimited and clear, the student can be given a clinical setting with consistent information that will close the gaps in practice. This clarity will allow a final result with a better performance of the future professionals and, consequently, a better care ${ }^{(5)}$. In this study, the first step in setting development was to determine the learning objective.

Thus, the definition of objectives and contents, in a clear and defined way in the simulation setting, allowed the health professional to identify the actions that need improvement, offering the opportunity to practice and develop skills, in a safe environment, far from care to the patient. Stress and anxiety are reduced, which increase the chances of error ${ }^{(4)}$.

It is necessary to establish guidelines for clinical simulation, since little evidence currently exists to guide professors who choose to use this teaching methodology ${ }^{(15)}$. However, there is a growing concern about the construction of settings for simulated practice, since the absence of a pedagogical roadmap for construction poses a threat to the effectiveness of clinical simulation. The setting was constructed to represent a delivery room to express realism, as identified in other studies that either used the delivery room itself or developed the simulation in an environment very similar to the real one $\mathrm{e}^{(2-3,13)}$.

In the process of construction of the setting, aspects were considered to motivate the reading and the learning of students. The setting can be considered very elaborate and realistic when it allows the subject a physical evaluation, training of technical skills and critical thinking in relation to the simulated situation. Thus, as observed in a performance evaluation list in clinical simulation, developed based on technical skills, knowledge and management in teams ${ }^{(2)}$. In view of this, judges were asked about the structure and presentation of the script. All agreed on the suitability of the material for undergraduates, also regarding the clarity of the language used and presentation and organization of the data $(\mathrm{I}-\mathrm{CVI}=1.00)$.

Judges' agreement on the construction of knowledge, based on the setting, was satisfactory, which proved to be adequate to the use of the same in the construction of knowledge on PPH. All students fully agreed that the scenario proposes knowledge on the subject through the use of active methodology. It is essential for the student to perceive the relevance and application of what is being taught and to be attracted to the educational material. The material should arouse interest in knowing something, when referring to real and meaningful situations for professional life ${ }^{(8)}$. 
All judges and students agreed that the setting could be used by health professionals or educators during PPH training. Periodic training with clinical simulation improves the performance of bimanual uterine compression and significantly improves the accuracy of blood loss estimation ${ }^{(12)}$. It is important to point out that clinical simulation is a feature to be used in nursing's Permanent Education as well. In addition, nurses acquire the necessary skills to assist obstetric patients in critical situations. Health professionals must pay attention to the needs of their target audience, using playful and realistic means that favor the interest and understanding of the subject. Thus, in the written communication process, textual elaboration must be suitable to the educational and cultural level of the target audience to be benefited by the educational material constructed ${ }^{(15-16)}$.

Regarding the validation process of content and appearance of this study, this was done through a tool with three categories of domains: objective, structure, presentation and relevance. Another study carried out the validation of a clinical simulation evaluation tool through relevance, clarity and feasibility. The tool was built in a checklist consisting of 20 items that maintain vital information, communication, feedback and communication behaviors ${ }^{(15)}$.

Content validation provided scientific recognition of the simulation setting, based on the judgment of expert judges, as observed in another study ${ }^{(15)}$. Judges agreed that the setting content promotes the construction of knowledge and considered appropriate the method for the use by health and education professionals. Coherence between content and objective had a satisfactory score, just like the logical sequence of the proposed content, a fact that indicates that the information contained in the setting is appropriate. In addition, the agreement with the information contained in the setting covers well the content and is important for the quality of care provided ${ }^{(17)}$.

\section{Study limitations}

There was a limitation of this study on the difficulty of judges to respond in a timely manner.

\section{Contributions to the fields of Nursing, Health or Public Policy}

Trainings based on clinical simulation are part of a proactive and appropriate approach to reduce errors and risks in Obstetrics by improving teamwork and giving students a multiplicity of skills and abilities to improve their performance.

Moreover, because it is an educational strategy, it will enable educators an innovative way to exchange knowledge with students and health professionals, provide the construction and reconstruction of knowledge, bring learning opportunities, and contribute to education advancement.

\section{CONCLUSION}

The validated clinical simulation setting was relevant and presented as a new teaching material of activities with nursing students in the discipline Women's Health/Obstetrics, with the objective of motivating students in the process of teaching learning, strengthening the theory/practice relationship, contributing to the training of more critical and reflexive nurses, and developing skills and abilities in the care of women with PPH. However, other studies should be carried out in order to test the effectiveness in increasing theoretical and practical knowledge of both nursing students and nurses during Permanent Education.

\section{PROMOTION}

There was no funding instituition.

\section{REFERENCES}

1. WHO Recommendations for the prevention and treatment of postpartum haemorrhage. WHO: Geneva. [Internet]. 2012 [cited 2016 Jul 20] Available from: http://www.who.int/reproductivehealth/publications/maternal_perinatal_health/9789241548502/en/index.html

2. Ruiz MT, Azevedo CT, Ferreira MBG, Mamede MV. Association between hypertensive disorders and postpartum haemorrhage. Rev Gaúcha Enferm [Internet]. 2015 [cited 2017 Jul 15];36(spe):55-61. Available from: http://dx.doi.org/10.1590/1983-1447.2015.esp.56776

3. Garbuio DC, Oliveira ARS, Kameo SY, Melo ES, Dalri MCB, Carvalho EC. Clinical simulation in nursing: experience report on the construction of a scenario. J Nurs UFPE Online [Internet]. 2016 [cited 2017 Jul 19];10(8):3149-55. Available from: doi:10.5205/ reuol.9373-82134-1-RV1008201645

4. O'Donnell J, Mann R, Martin D. Simulation training for surfactant replacement therapy: Implications for clinical practice. J Neonatal Nurs [Internet]. 2014 [cited 2016 Jul 28];20(6):283-9. Available from: http://dx.doi.org/10.1016/j.jnn.2014.04.002

5. Christian A, Krumwiede N. Simulation enhances self-efficacy in the management of preeclampsia and eclampsia in obstetrical staff nurses. Clin Simul Nurs [Internet]. 2013 [cited 2016 Jul 20];9(9): e369-77. Available from: https://doi.org/10.1016/j.ecns.2012.05.006

6. Polit DF, Beck CT, Hungler BP. Fundamentos de pesquisa em enfermagem: métodos, avaliação e utilização. 5 ed. Porto Alegre: Artmed; 2011 .

7. Fehring RJ. Methods to validate nursing diagnose. Heart Lung [Internet]. 1987 [cited 2019 Mar 12];16 (6 Pt 1):625-9. Available from: https:// pdfs.semanticscholar.org/11f7/d8b02e02681433695c9e1724bd66c4d98636.pdf

8. Lopes MV, Silva VM, Araujo TL. Methods for establishing the accuracy of clinical indicators in predicting nursing diagnoses. Int J Nurs Knowl [Internet]. 2012 [cited 2016 Jul 20];23(3):134-9. Available from: https://doi.org/10.1111/j.2047-3095.2012.01213.x

9. Sampieri RH, Collado CF, Lucio MPB. Metodologia da pesquisa. 5 ed. Porto Alegre: Penso; 2013

10. Jeffries PR. A framework for designing, implementing, and evaluating simulations used as teaching strategies in nursing. Nurs Educ 
Perspect [Internet]. 2005 [cited 2019 Mar 12];26(2):96-103. Available from: https://journals.Iww.com/neponline/Abstract/2005/03000/A FRAMEWORK_for_Designing,_Implementing,_and.9.aspx

11. Gutierrez F, Quilici, AP. Simulação Clínica: do conceito à aplicabilidade. São Paulo: Atheneu, 2012.

12. Nomura RM, Novoa YNVA, Pimenta BS, Nakamura MU, Moron AF. [Validation of a questionnaire to evaluate the experience and selfconfidence on emergency assistance in vaginal delivery]. Rev Bras Ginecol Obstet [Internet]. 2014 [cited 2019 Mar 12];36(11):519-24. Available from: https://doi.org/10.1590/SO100-720320140005100 Portuguese.

13. Waxman KT. The development of evidence-based clinical simulation scenarios: guidelines for nurse educators. J Nurs Educ [Internet]. 2010 [cited 2016 Jul 15];49(1):29-35. Available from: https://doi.org/10.3928/01484834-20090916-07

14. Dadiz R, Weinschreider J, Schriefer J, Arnold C, Greves CD, Crosby EC, et al. Interdisciplinary simulation-based training to improve delivery room communication. Simul Healthc [Internet]. 2013 [cited 2019 Mar 12];8(5):279-91. Available from: https://doi.org/10.1097/ SIH.0b013e31829543a3

15. Oliveira PM, Pagliuca LM. Assessment of an educational technology in the string literature about breastfeeding. Rev Esc Enferm USP [Internet]. 2013 [cited 2015 Jul 15];47(1):201-8. Available from: http://dx.doi.org/10.1590/S0080-62342013000100026

16. Melo GP, Andreto LM, Araújo MVG, Holanda VR. Creation and validation of a nursing assistance protocol for the prenatal, delivery and recovery room. Rev Eletr Enf [Internet]. 2016 [cited 2018 Jan 23];18:e1204. Available from: http://dx.doi.org/10.5216/ree.v18.40589

17. Oliveira SC, Lopes MVO, Fernandes AFC. Development and validation of an educational booklet for healthy eating during pregnancy. Rev Lat Am Enferm [Internet]. 2014 [cited 2016 Jul 30];22(4):611-20. Available from: https://doi.org/10.1590/0104-1169.3313.2459 